\title{
Economic Policy and Open Innovation Ecosystems: Biomedicine Case
}

\begin{abstract}
The paper overviews different perspectives of innovations in the economy. Taking empirical data of the biomedicine sector, the EU policy insights on innovation, as well as Lithuania's data of the public healthcare sector, the paper provides insights aiming to define the specificity of innovations in the biomedicine sector and to suggest further research directions which could contribute economic theory and practice.
\end{abstract}

Keywords: open innovations, economic policy, trust theories, biomedicine.

Straipsnyje išskiriant svarbias šiuolaikines inovacijų skatinimo ekonomikoje teorijas, remiantis empiriniais biomedicinos sektoriaus duomenimis, ES politinèmis gairèmis ir Lietuvos viešojo sveikatos sektoriaus duomenimis, suformuluota inovacijų svarbos ir sklaidos šiame sektoriuje specifika, teikiamos įžvalgos ir rekomendacijos tolesniems tyrimams, kurie pagerintų teorines ir praktines žinias.

Raktiniai žodžiai: atvirosios inovacijos, ekonomikos politika, pasitikejjimo santykių teorijos, biomedicina.

\section{Introduction}

Current technological advancements in life sciences (biological sciences that involve the scientific study of life and organisms) play an important socio-economic role both within national economies and on the global scale by improving the quality and standard of life through many different pathways - healthcare-related industries, agriculture, food industries and so on.

With ageing population worldwide, the importance of healthcare technologies efficiency becomes increasingly important not only from an economic standpoint but also as a socio-economic solution for many governments in balancing the government's spending. However, while the potential benefits are widely desirable, the structures and mechanisms of innovation fostering and economic value creation from it are often defined by high levels of complexity and uncertainty by both governments and economic agents.

It is widely accepted that biomedical innovations and dissemination of technologies into clinical practice/accessibility of innovative treatments have direct effects on all levels of society and the economy in general. Furthermore, it is assumed that innovations spin of new circles of socioeconomic potential for national wellbeing accumulation. However, practice shows that natural market forces often fail to facilitate sufficient in terms of scope and speed the economic conversion of applied scientific knowledge into clinical practice. Next to that, important questions of how 
to cope with all the related risks on both micro and macro levels of a country for a balanced and sustainable development of the country's economy come into the spotlight of both economic agents and governments.

Given the above-provided context, the scientific problem of this article is the economic policy of open innovations' specificity in biomedicine.

The aim of this article is to highlight elements of complexity of innovation management within the economy using the specific case of biomedicine and by doing so suggest directions for further investigations on how economic policy could and should be used as market inefficiency or certain market forces absence compensating instrument for creating innovation fostering environment, which would both support private sector's innovation efforts and accumulate higher socio-economic value within the economy.

The object of the article is economic policy and open innovation ecosystems.

The methods to prepare the article included gathering of related articles online, analysis of theoretical discussions and empirical data in scientific articles, EU economic policy documents, aggregation of insights, generalization, and interpretation, based on inside healthcare industry experience of the author.

\section{Open innovation ecosystem's theories for framing innovation- driven industry and the role of trust in fostering changes}

The growing appreciation of an ecosystem's principles for innovation is not only a rapidly broadening scientific analysis field but also a global trend among governments and business institutions worldwide.

Not surprisingly, systemic and synergic "cultivation of favorable environments to encourage multiple local innovators to cooperate" and capture economic value through co-created knowledge (Frenkel and Maital, 2014; Iansiti and Levien, 2004) look attractive. However, this notion of openness in innovation ecosystem carries significant challenges in understanding the multi-layered complexity of interactions in practice, when searching for the most suitable solutions in each individual case. In particular, as some scholars point, "innovation ecosystems require specific attention when faced with fast-developing emerging industries that closely link science, technology, and business" (Xu et al., 2017).

The central idea of successful open innovation ecosystems is that they allow companies to create value that no single firm could have created on its own. Next to value externalities within the open innovation ecosystem, these studies also point to the medium of the open innovation ecosystem, which shapes the interactions and coordination needs between the leading and niche players, as well as the integration of value complementariness across the value chain of the innovation ecosystem (Adner, 2006; Battistella et al., 2013; Oh et al., 2016, cited by Xu et al., 2017).

As Korean professor Deog-Seong Oh, a member of UNESCO High Panel on Science for Development, points, it is important to acknowledge and highlight that an open innovation ecosystem contains within itself two distinct ecosystems - the knowledge ecosystem, driven by fundamental science, and the business 
ecosystem, driven by the marketplace forces (Oh et al., 2016, cited in Xu et.al., 2017). While the knowledge ecosystem is driven by R\&D output, businesses operate following market economies and demand side feedback. Therefore, knowledge creation in the knowledge community and value capturing of novel technologies in the business ecosystem should be both of equal importance yet acknowledged separately when examining open innovation ecosystems (Clarysse et al., 2014, cited in $\mathrm{Xu}$ et al., 2017). Divergencies in drivers and purposes embed the fractioned nature of open innovation ecosystems and potentially disrupted transitions of knowledge as well as commercialization of technologies, which may be trapped in between of gaps of dependent yet not sufficiently connected individual institutional or individual agents within the open innovation ecosystem.

In such cases, open innovation ecosystems purposefully aim to seek novel technological solutions through the resources of knowledge ecosystems within the open innovation ecosystems to create nonexisting user benefits and, therefore, can hardly naturally integrate into the existing socio-economic structures of the related industries without an external support for integration, risk sharing and, equally important, competence transfers among the related agents.

Corresponding to the market globalization's extent and depth, which is further reinforced by developments in information technologies and artificial intelligence lately, the works of many authors have attempted to incorporate internationalization of open innovation ecosystems. Some authors, like E. G. Carayannis and D. F. Campbell (2009, cited by Xu et al., 2017) looked beyond the technological aspects of innovation ecosystems to see the importance of non-technological elements in building up the competencies of innovation ecosystems to grow and get stronger, urging one to look beyond the technological aspects of innovation ecosystems to see the importance of non-technological elements in building up the efficiency and competitiveness of open innovation ecosystems.

The take away of these statistically grounded observations is that the open innovation ecosystem's coordinated management is always conditioned by a wider socio-economic context of the country where it emerges and develops.

Finally, as theory claims and the dynamics of the global biomedicine industry confirm, distances and types and levels of involvement/roles of different institutions in the open innovation ecosystem are different and require precision in understanding specifics of their participation in the overall value creation chain of the ecosystem. For instance, sufficient involvement of financial actors has only recently been acknowledged as one of the key success factors (Clarysse et al., 2014, cited by Valkokari et al. 2017).

All the argumentation leads to the concept of "the essential ecosystem competence" (Valkokari et al., 2017) that is needed by all actors in an ecosystem and is the ability to manage dynamic strategic interactions related to innovation. As it is argued by academics, this competence enables them to ensure the future vitality of the ecosystem and their own business. The examples of US origin international pharmaceutical giants' dominance in the absorption of newly evolving biotechnologies worldwide nicely illustrate one of the 
ways how dominating players shape the innovation ecosystem by setting clear rules and steps, which enable market forces to take over innovation commercialization at certain stages of its development. Sometimes, in a positive way by enhancing the potential through financial mechanisms. Yet sometimes also working in a negative way by putting the technologies off-shelf in order to protect profits from existing on the market technologies and eliminate any competitive threats.

The theory suggests that "ecosystem management can be divided into composing and orchestration tasks" (Valkokari, Valkokari, 2014). These are two distinct goals in gathering and sustaining value creation within the innovation ecosystem. Since companies "typically see their networks and other inter-organizational relationships from their own perspectives rather than emphasizing ecosystem-level viewpoints" (Valkokari, 2014), an external sum of coordinated processes, led by an ecosystem leader (Adner, 2012, cited by Valkokari et al., 2017), or an ecosystem coordinator (Jansen, Cusumano, 2013, cited by Valkokari et al., 2017) is seen as needed element for the ecosystem to be successful.

Moreover, some authors point, that cooperation in the open innovation ecosystem "requires a large amount of brokerage effort to form alliances and ultimately share information", creating and sustaining "the absorptive capacity for knowledge exchange" (Giest, 2019).

While the expanded view on theoretic discussions enrich the set of tools for analyzing the economy's innovation structure, the underlying means of the processes which enhance or reduce the speed of innovation remain out of the scope of the theories discussed, leading the attention towards the elements of trust within the economy and the extent of positive policy implications on accumulating trust within the innovation ecosystem.

Given the complexity of factors affecting the pace of innovation within the ecosystem and contradicting interests of cooperation and competition among the stakeholders, level of trust arguably becomes the deciding factor for how smoothly implicit and explicit interactions are happening and what is the strength of the links between the members of the ecosystem.

As it is noted by numerous authors, trust is "a commodity that permits voluntary participation in production and exchange in such networks" (Giest, 2019). What is further important, even if explicitly managed, trust among separate members of the ecosystem has its own dynamics and raises different challenges as the relationships and cooperation among the institutional entities (business or scientific) and individuals within them evolve over time.

Even though trust creates collaborative dynamics in a competitive setting, the trust itself emerges either through common history and repeated interaction or, if fostered purposefully, by establishing trust compensating mechanisms through institutional or legal means.

Henry Farrell, the assistant professor of George Washington University, presented handy to the analysis view in his work "Institutions and Mid-Level Explanations of Trust" (2009, cited by Giest, 2019). His conceptualization of trust incorporates the realm between the individual and the highly abstract level of trust. The idea is based on Hardin's (2002) insight that personal trust can be rooted and built upon 
trusting a certain group or class rather than separate individuals. In that case, individuals 'borrow' trust credits from the groups to which they belong reputation.

On the macro level of the economy, the starting point of initiating institutionalized trust development is industry and sector specific policies and their implementation in the legislative framework. Therefore, policy evaluation theories must be integrated into the analysis of the open innovation ecosystem's development in order to grasp the complex context within which the results of the thesis can be later integrated for the scientific and practical knowledge enhancement.

In order to enable and assist the function of national open innovation ecosystems, governments intervene and participate through policy setting and enablement. Policymaking processes are based on planning, which calls for arguments and informed predictions about the future. The extent of scope of unknown factors when analyzing innovation processes, especially in the case of disruptive technologies, generates solid debate and academic research output on how to understand, structure and manage analysis and forecasting to make it useful and integrable into political and public discussions during the policy-making and implementation processes.

As the British economist, Abdullah Gök has summarized in 2010, "the national system of innovation, including the policy instruments used for STI (science, technology and innovation) policy formation, is a complex socio-economic system that involves innumerable individuals and organizations that contribute both $\mathrm{di}$ rectly and indirectly to the production of scientific and technical knowledge. The interaction of various economic agents within these systems are so complex, even selection models do not fully understand them" (Ramberg, 2012).

At the same time, there is general agreement that the level and extent of non-coordinated privately initiated $\mathrm{R} \& \mathrm{D}$ activities result in lower knowledge and technological development output levels than what would be optimal for the society. Therefore, science, technology and innovation (STI) policies are seen as instruments "to overcome the systematic tendency toward underinvestment" (Ramberg, 2012). Policy evaluation methods aim to assist academic and practical grounding when evaluating the effectiveness of these policies.

Another important aspect to have in mind is that the extensive scientific data on differences in innovation patterns between mature and developing economies, the importance of accumulated competencies and availability of social, as well as monetary funds may provide handy quantitative and economic rationale-based parallels for the government participation in open innovation ecosystems.

What is interesting, that in practice the approach taken by the OECD is based on public value mapping of science model (referred to as PVM), putting social value above direct economic outcome measurement. This model, based on public value theory, is used as a set of assumptions and procedures in the case study method, used by OECD to analyze planned or projected research activities, evaluate and draw conclusions on their potential impact for individual countries, as well as draw recommendations for policymaking.

The OECD report names four important contextual factors, which define the 
scope and nature of the social impacts of research, science and technology policies:

- Characteristics of the knowledge produced by the research;

- Institutional arrangements and management affecting knowledge production and use;

- Policy and political domains of knowledge production and use (the political, legal, public policy and normative factors that determine research choices, utilization, and impact);

- Market settings for knowledge production and use (markets, quasi-markets or government entities).

While in theory, all the models for open innovation analysis discussed so far provide handful insights into separate areas of innovation-related issues, the practical value of theories is always tested in practice where real-world reflections clearly point where quality academic thinking and practical understanding are in need of deeper attention both by the scholars, government officials, politicians, businesses and the society.

\section{Global competition for innovation capacity and biomedicine}

Science, Research and Innovation Performance of the EU (2018) report's data shows that pressure in the global competition for innovation capacity among the economies worldwide is getting more intense (Figure 1). While the EU part remains significant, China, as well as other Asian countries are rapidly catching up on the global arena, building solid grounds for further economic power expansion in the age where the ability to innovate fast and convert it into economic value through technology dissemination becomes one the critical if not the most critical factor of success both for the economies and businesses.

European Commission confidently argues that the pace of biomedical innovation and the dissemination of life science technologies in clinical practice, accessibility of innovative treatments directly affects every economic agent of a country's economy on individual, institutional and national levels and catalyzes new opportunities for greater wellbeing creation and economic value generation (Open Innovation book, 2016). It is also believed that technological innovation would be one of the contributing factors for timely and economically efficient restructuring of healthcare systems, helping EU member countries' governments to ensure fiscal sustainability for the public sector and stimulate openness for innovations at the same time, promoting synergies for all economic agent's involved, as well as reasonable risk diversification among public and private sectors.

The Burden Survey, conducted by the European Commission in 2018, confirms the necessity to regularly measure how compatible and supportive are the EU regulations for innovation and investments which could stimulate economic growth and creation of qualified workplaces. In the EU Commission's documents, it is admitted that "the most important challenge is to put in place a regulatory framework that can adapt to the pace of change of new technologies and new forms of innovation" (Better regulations for innovationdriven investment at the EU level, 2016). In the same document, the EU Commission also recognizes the need to achieve openness among the EU state members for 


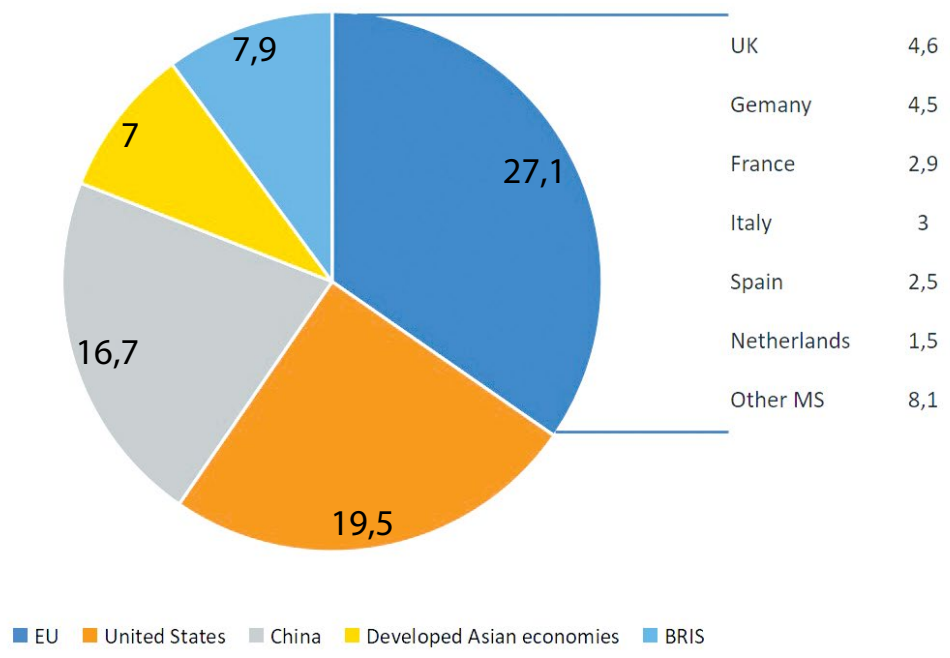

Fig. 1. The world share of scientific publications in 2016

Source: The EU Commission's report "Science, Research and innovation performance of the EU 2018” (2018).

empowering the EU Single Market scale and scope in order to allow technological newcomers "to challenge incumbents and increase Europe's ability to attract mobile international inward investment" and restore diminishing role of the EU on the global scale of R\&D and technological innovations' developments.

What is important to point is that the ongoing developments continuously influence regulative thinking. The Open Innovation book (2016), prepared by the EU Commission, summarizes, that the concept of Open Innovation is constantly evolving and is moving from linear, bilateral transactions and collaborations towards dynamic, networked, multi-collaborative innovation ecosystems. A specific innovation is no longer 'the result of predefined and isolated innovation activities' but in most cases, it is 'an outcome of a complex co-creation process involving knowledge flows across the entire economic and social environment'.
The global context of challenges and resources, as well as emerging boundaryfree, technologically based opportunities in most cases, redefine the boundaries of innovation ecosystems and call for the internationalization of R\&D and innovation. As statistical data of OECD Science, Technology and Industry scoreboard shows, the intensity of R\&D grows and so does the multi-polarization on the global scale, reducing the relative weight of European R\&D. China firmly moves forward, increasing their investment in R\&D dramatically over the past 20 years (OECD Science, Technology and Industry scoreboard, 2015). This spins-off further cascade of weakening effects on competitiveness and foreign direct investment attraction both to the EU and even so to less developed member countries within it.

On the other hand, the remarkable success of China also provides handful insights and statistical data to have a closer look when defining the priorities in 
policies by, for example, testing the change of attitude for sequencing targeted results and their overall interaction within the open innovation ecosystem for the generation of economic competitiveness for the national economy.

Moving to another global trend, the role of networking is seen as one of the key trends in reshaping the whole global competition. In particular, this is true in the case of the global healthcare industry. Public involvement in the decision making, technological developments as well as shift of focus from products to therapies, from generalized to personalized view of the patient, have led partnering strategies both on national and global levels to evolve into thousands of simultaneous interactions between the ecosystem participants, which play alongside the companies' internal drug development dynamics, ability to differentiate and win time to the market competition in the complex matrix structure of nowadays completely global innovation ecosystem of healthcare sector.

This is most likely a result of a complex set of factors, that affect interest and ability of different businesses to invest into $\mathrm{R} \& \mathrm{D}$, level of trust, skills to differentiate between value creation processes in open sharing and internal differentiation competencies, all of which sum up into risk tolerance, accepted by business and governments within national economies. And it is likely, that these contextual factors shape the statistics, which indicates, that despite all the fast-growing appreciation of vast opportunities that open innovation ecosystems bring to the economy, the reality proves that in practice innovation ecosystems often fail to function smoothly. In Lithuania both private and public institutions face significant internal and external obstacles in the coordination of decisions and processes, failing to co-create value both in economic and social welfare terms, which reinforces the need for structural changes within the national ecosystem in order to preserve any chances for global competitiveness.

The history of multiple failures to engage efficiently, lack of managerial (in private sector) and governance (in public sector) competencies, external and internal complexities, financial risks, associated with investments into technological innovations, as well as reputational risks, which play a hard card in biomedicine and medical devices' industries- often enhance rather than reduce lack of trust among the agents in the economy. Lack of interest to engage among science and business representatives in Lithuania is clearly confirmed by Science and Studies Monitoring and Analysis Center's report on low levels of cooperation between science and business institutions and reasons of that (Science and Business cooperation on scientific research and experimental activities, 2018), where lack of interest to engage between scientific and business institutions was being analyzed.

As one of the results illustrating the consequences of incompetent policy application effect for the economic society can be taken the data on Lithuanian public healthcare, which clearly points to the problems of the public healthcare sector in its poor ability to create value through health benefits (Table 1).

What is important to stress, that while there is clear consensus on preferred goals of efficiency, the implementation of recommendations (drugs' price control initiatives, public hospital's network optimization through regional hospitals' closure, 
Table 1. Average efficiency scores by health outcome of national health care systems in the EU

\begin{tabular}{|c|c|c|c|c|c|c|c|c|}
\hline & $\begin{array}{l}\text { Life expectancy } \\
\text { at birth, years }\end{array}$ & $\begin{array}{l}\text { Healthy life } \\
\text { expectancy at } \\
\text { birth, years }\end{array}$ & $\begin{array}{c}\text { Life } \\
\text { expectancy at } \\
\text { age } 65, \text { years }\end{array}$ & $\begin{array}{l}\text { Healthy life } \\
\text { expectancy at } \\
\text { age } 65 \text {, years }\end{array}$ & $\begin{array}{c}\text { Amenable } \\
\text { mortality }\end{array}$ & $\begin{array}{c}\text { Life } \\
\text { expectancy at } \\
\text { birth } \\
\text { according to } \\
\text { Heijink R. et.al } \\
\text { (2015), years }\end{array}$ & $\begin{array}{c}\text { Healthy life } \\
\text { expectancy at } \\
\text { birth } \\
\text { according to } \\
\text { Heijink R. et.al } \\
\text { (2015), years }\end{array}$ & \\
\hline AT & 0,98 & 0,92 & 0,94 & 0,83 & 0,51 & 0,98 & 0,94 & AT \\
\hline $\mathrm{BE}$ & 0,98 & 0,92 & 0,93 & 0,85 & 0,68 & 0,98 & 0,94 & $\mathrm{BE}$ \\
\hline BG & 0,97 & 0,91 & 0,95 & 0,8 & 0,48 & 0,96 & 0,95 & BG \\
\hline $\mathrm{CY}$ & 0,99 & 0,96 & 0,97 & 0,83 & 0,64 & 0,99 & 0,97 & $\mathrm{CY}$ \\
\hline $\mathrm{CZ}$ & 0,94 & 0,81 & 0,88 & 0,64 & 0,33 & 0,94 & 0,89 & $\mathrm{CZ}$ \\
\hline $\mathrm{DE}$ & 0,98 & 0,9 & 0,95 & 0,87 & 0,51 & 0,98 & 0,95 & $\mathrm{DE}$ \\
\hline DK & 0,97 & 0,86 & 0,93 & 0,86 & 0,58 & 0,97 & 0,94 & DK \\
\hline $\mathrm{EE}$ & 0,96 & 0,93 & 0,91 & 0,76 & 0,53 & 0,95 & 0,91 & $\mathrm{EE}$ \\
\hline EL & 0,98 & 0,93 & 0,95 & 0,8 & 0,55 & 0,98 & 0,95 & EL \\
\hline ES & 0,99 & 0,96 & 0,96 & 0,86 & 0,66 & 0,99 & 0,97 & ES \\
\hline $\mathrm{FI}$ & 0,98 & 0,94 & 0,95 & 0,87 & 0,5 & 0,97 & 0,96 & $\mathrm{FI}$ \\
\hline FR & 0,99 & 0,97 & 0,95 & 0,92 & 0,81 & 0,99 & 0,95 & FR \\
\hline HR & 0,98 & 0,92 & 0,91 & 0,71 & 0,52 & 0,98 & 0,94 & $\mathrm{HR}$ \\
\hline HU & 0,95 & 0,88 & 0,91 & 0,71 & 0,38 & 0,96 & 0,92 & $\mathrm{HU}$ \\
\hline IE & 0,98 & 0,92 & 0,97 & 0,89 & 0,53 & 0,97 & 0,97 & IE \\
\hline IT & 0,99 & 0,95 & 0,93 & 0,74 & 0,74 & 0,98 & 0,92 & IT \\
\hline LT & 0,92 & 0,87 & 0,85 & 0,54 & 0,33 & 0,92 & 0,87 & LT \\
\hline LU & 0,98 & 0,92 & 0,94 & 0,87 & 0,7 & 0,97 & 0,94 & LU \\
\hline LV & 0,95 & 0,91 & 0,91 & 0,74 & 0,42 & 0,95 & 0,93 & LV \\
\hline MT & 0,98 & 0,91 & 0,97 & 0,88 & 0,53 & 0,98 & 0,97 & MT \\
\hline NL & 0,99 & 0,91 & 0,98 & 0,95 & 0,73 & 0,99 & 0,98 & NL \\
\hline PL & 0,95 & 0,92 & 0,91 & 0,7 & 0,48 & 0,96 & 0,92 & PL \\
\hline PT & 0,98 & 0,95 & 0,93 & 0,74 & 0,53 & 0,98 & 0,93 & PT \\
\hline RO & 0,98 & 0,93 & 0,95 & 0,79 & 0,38 & 0,98 & 0,95 & Ro \\
\hline SE & 0,99 & 0,93 & 0,98 & 0,93 & 0,54 & 0,98 & 0,97 & SE \\
\hline SI & 0,97 & 0,92 & 0,91 & 0,74 & 0,53 & 0,97 & 0,92 & SI \\
\hline SK & 0,92 & 0,8 & 0,84 & 0,5 & 0,24 & 0,92 & 0,85 & SK \\
\hline UK & 0,98 & 0,93 & 0,96 & 0,91 & 0,53 & 0,98 & 0,97 & UK \\
\hline
\end{tabular}

Source: European Commission. Directorate-General for Economic and Financial Affairs (2015).

etc.) without taking into account certain cultural, historical, social and economic factors, as well as fully ignoring the analysis of full healthcare supply chain operations and competencies, carries, in my opinion, a much higher risk of further decreasing the system's current efficiency. The government's focus on cost containment almost 
immediately closes the doors for biomedicine innovations dissemination in practice for such simple reasons like inappropriate comparison of existing alternatives with the often more expensive yet also more efficient new-coming technologies, excluding the full cost of the patients' treatment and his/her ability to return to work faster due to more efficient treatments, enabled by available to use innovations.

Another global trend, caused by remarkable discoveries and innovations in the biomedicine field- a major shift of focus in medicine in general-from standardized by treatment protocols medicine to a personalized approach, which call for dramatic changes both in pharma industry and clinical practice, further complicates the search of short term cure for fiscal problems in the healthcare budget. The rise of precision medicine alone gives the new dimension to the healthcare as the sector, reshaping the traditional medicine as we know it now, which emerged in the $18^{\text {th }}$ century in the context of industrial revolution by changing the principles how the industry and its supply chains will be shaped by the existing and upcoming innovations in the very near future of the coming 20 years or so. Therefore, Lithuanian government faces an even more tricky task of answering the question how it plans to accommodate and manage future risks of not being able to generate and/or disseminate innovation in clinical practice if current cost containment policies damage the healthcare system's ability to follow the global changes in healthcare (Figure 2).

The fundamental shift from 'one-size fits all' to 'one-size fits one', initiated by such remarkable innovations as gene editing, stem cell therapies, cancer immune therapies, robotics, advancements in neuroscience, Big Data phenomenal opportunities and Artificial Intelligence (AI) technologies demand significant changes in every possible way to accommodate not only the needs of all the stakeholders in the open innovation system of biomedicine but also find new ways to organize all the processes and decision making in the matrix, rather than linear supply chain of healthcare provision to the patients.

The contradicting challenges, faced by healthcare sector and related industries, call for a necessity not only to intervene through institutionalized and legal instruments with a goal to prioritize and structure common economic and social targets, as well as secure fiscal sustainability of the public healthcare sector but also do this in an integrated and coordinated manner. The Burden Survey (2015), prepared by the EU commission stresses that cost and benefit analysis of the existing legislation must be continuously reviewed to reduce burdens and aim for the real-time economy (RTE) principle, "which is an environment where financial and administrative transactions between citizens, businesses and public sector entities are in structured, standardized digital format, generated automatically and thus completed in real time". In theory, all the technologies and tools are already present and rapidly evolving with developments in Big Data management and AI technologies, available both for the governments and other stakeholders. Yet the situation in many countries is far from idealistic models and recommendations not only due to financial constraints of implementation but also competencies, skills and willingness of the leaders and decision-makers to change not only processes but also mindsets of all the stakeholders in the economy. 


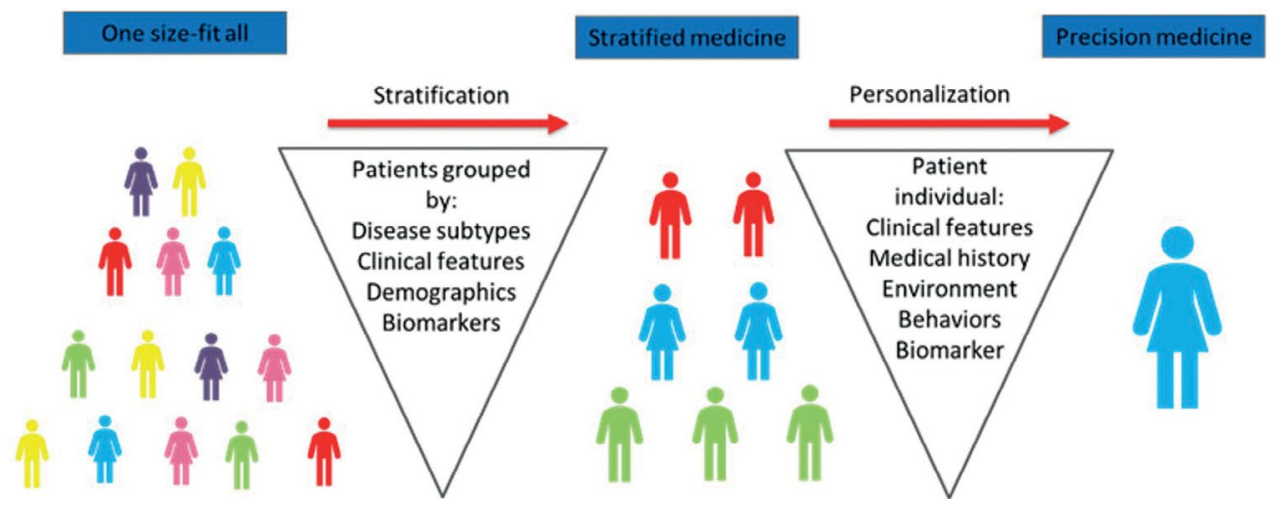

Fig. 2. The emergence of precision medicine and the radical shifts it presents in modern medicine

In Lithuania, the government allocates the task of creating and applying policy tools to foster open innovation ecosystem of life sciences, including biomedicine, between the three ministries: The Ministry of Economy and Innovations, The Ministry of Health and the Ministry of Education, Science and Sport. The lack of vision integration for how innovation should be fostered and efficiently integrated into practice between the three ministries is especially clearly felt in the case of life science innovations. While the Ministry of Economy and Innovation see it as one of their top priorities to promote and support, counting all the economic benefits the technologies can generate for the country's economy and international competitiveness, The Ministry of Health at the same time is fully dedicated towards cost containment initiatives and removal of the most widely cited statistical shortcomings of Lithuanian public healthcare system, as well as coping with fiscal sustainability threats in the public healthcare sector. In other words- correcting the minuses from the past rather than developing future supporting ecosystems, needed to utilize the new coming technologies in the clinical practice and by doing so- aim to optimize the efficiency of the system.

What is interesting to notice is that following the economic paper by the European Commission "Efficiency estimates of health care systems"(2015), "efficiency gains can be measured in two ways: either by increasing health outcomes, while keeping inputs at current levels (outputorientation), or by decreasing inputs, while keeping health outcomes at current levels (input-orientation)". Since Lithuania's life expectancy of 73,7 is far below the benchmark of 80 years of age, which is seen as breaking point for return efficiency of gaining more years outcome from increased resource use, there is sound base to conclude that output-orientation would be a more suitable approach to take for Lithuanian government in healthcare sector's management. Theoretically, this could receive less resistance among healthcare professionals and the public than current reforms, as well as create more supportive environment for the sector to embrace the opportunities of innovations and become more active participants in shaping 
the biomedicine's efficient development through demand-side directions where and what kind of innovations are most needed to achieve the joint goal of output efficiency improvements (Figure 3).

However, another document by the European Commission, Cost-Containment Policies in Hospital Expenditure in the European Union (2016) explicitly stresses "that the reorganization and rationalization of hospital care... is an important factor towards cost containment and possibly increasing the quality of care". Even though it is admitted in the same document that "higher income countries have been able to reduce bed capacity than lower income countries due to a variety of factors such as the availability of investment capital and the introduction of modern medical technology, which reduces the need for more beds", the focus of recommendations remain on cost controlling tools and reduction of hospitalization by $20 \%$ is seen as one of the goals to be set for Lithuanian healthcare system to improve its efficiency. This obvious oversimplification of the public healthcare management recommendations through fiscal lenses, taken by the healthcare authorities in Lithuania, based on the EU observations and neither scientifically, nor statistically firmly proven recommendations, which is admitted in the same document, not only carries high risk failing to achieve coherent overall improvement of the healthcare efficiency but also cause further delays in technological advancements of clinical practice.

Moving back from clinical practice to accumulated public knowledge creation stage in Lithuania, the publicly declared priorities of the Ministry of Education, Science and Sport seem to be even further away from taking active role in strengthening and shaping open innovation ecosystems due to their self-sustained focus on the knowledge creation ecosystem alone and its general performance indicators, such as education accessibility, lifetime learning and studies' quality. All of which are important yet too general for the fastpaced innovation defined industries like biomedicine.

\section{Conclusion}

What is obvious from real-world data, that the reality of open innovation ecosystems explains why a single theory would stand no chances to cope with the complexity of the phenomenon and only an integrated set of theories and facts must be used in the analysis, especially if it carries the purpose of the decision making at any level of the economy.

Furthermore, the heterogeneity of findings among other things points to the importance of soft yet critical factors differences in the level of trust not only in the ecosystems but also the national economies, differences in the capacity of the economic agents to benefit from the supporting elements and other processes within the economy. The dependency on each other, compulsory co-evolution of capabilities (with either positive or negative dynamics) and other shared commonalities by all related economic agents do not unify internal competences of the business or science institutions to innovate and adapt timely within the same open innovation ecosystem. Theory claims, that an attempt to compensate lack of trust and common understanding among the stakeholders and create supportive environment 


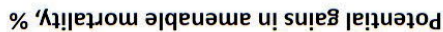

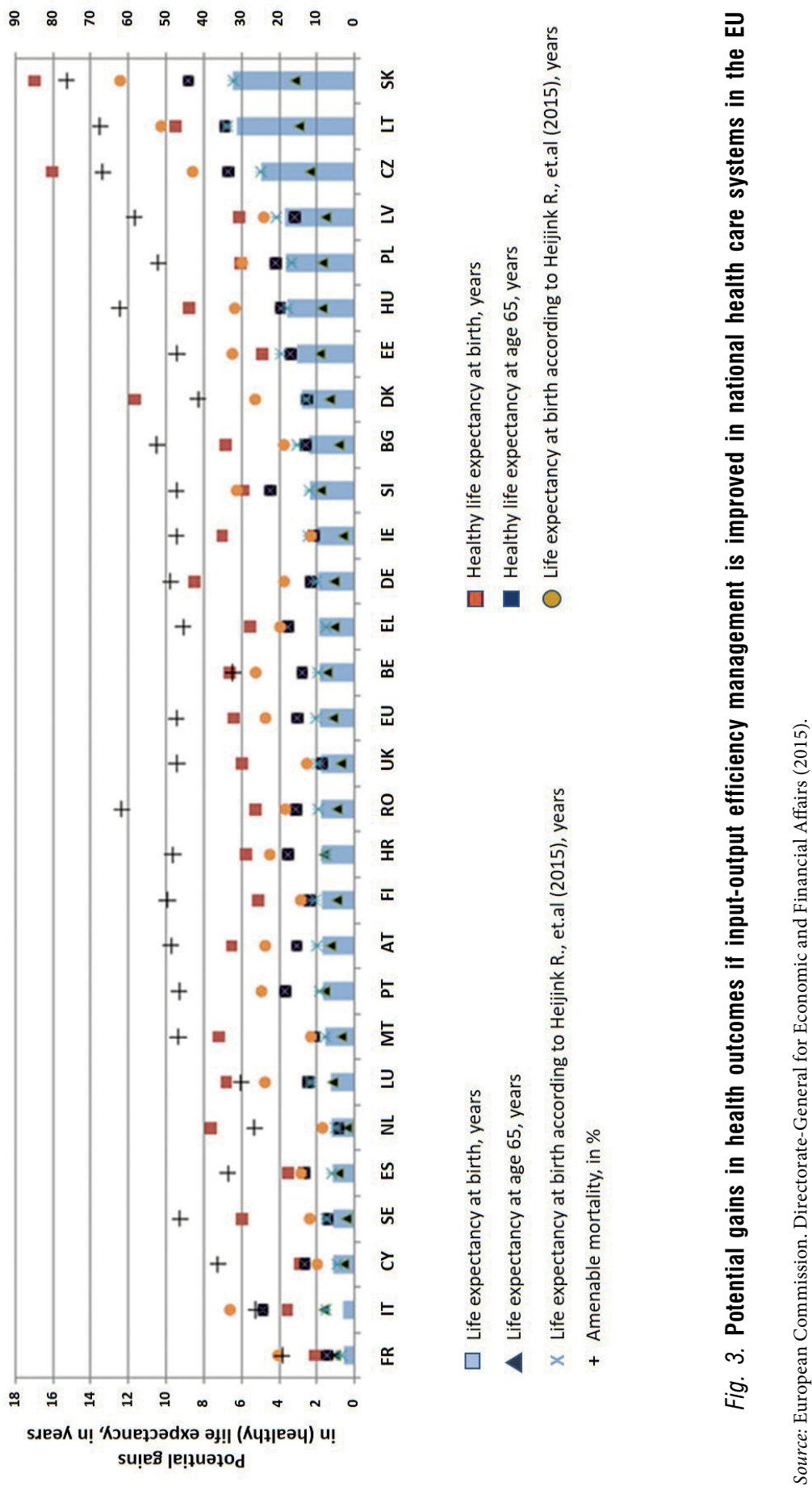


for free market forces to function through suitable economic policies and institutionalized cooperation stimulators could arguably foster more efficient innovation incubation and conversion to economic values through better informed decision making on the macro and microeconomic levels, as well as more leveraged risk management.

The third conclusion is that when making the decision, in particular on the macro level, where the responsibility for the nation is accumulated, one has to deal with the complexity on all levels: rational and irrational arguments, vertical and horizontal interconnectedness of the social and economic results (making everyone to an extent a stakeholder in innovation's assimilation process), all of this being deeply embedded historical and cultural context. This makes the decision process for biomedicine development extremely complex, claiming the need for regulations to reduce complexity and variation of possible outcomes (in particular control of risks) for individuals and governments to what is accepted as "normal". On the other hand, like any other innovation process, biomedical innovations call for certain supporting environment to deliver sustainable value and become a vital part of the existing/ functioning healthcare system. Meaning, that all supporting academic, technological, economic and social structures and decision power holding agents have to be of adequate competence, be sufficiently informed and share sense of trust to be able to support this integration, whenever as part of the existing ecosystems or even more when the technologies are completely rewriting the underlying human understanding of the word and human beings, questioning fundamental understandings of ourselves and drawing new lines for what is moral and ethical. On the macro level in particular this leads to the search of ways how to structure the complexity and support selection process for confirming legitimacy of practices and technologies whose benefits are believed to outweigh any related risks. Legal regulative framework of any country is shaped by direct decision making of government officials, based on available source of "objective" information (namely statistics), as well as dominant cultural and moral values of the nation, level of trust which set the framework of data interpretation within the political context. And the "real time economy" notion, used by OECD is already a must in practice, not a recommendation in theory.

Returning from theoretical generalizations back to the practical issues, one of the key issues that open innovation ecosystems definitely face in practice is lack of systemic and coordinated approach on the policy making and implementation level, which could stimulate economic conversion of technologies into commercial success and offer higher transparency rates. This, in turn, could contribute directly and indirectly towards trust stimulation mechanisms among the stakeholders of the innovation ecosystem- a critical element for self-correcting mechanisms to be established within the open innovation ecosystem.

The context of the empirical data, collected by the EU and the theoretical discussion above confirm that innovation pace is a sum of extremely complex factors, multiple continuous interactions between a wide set of related stakeholders, socio-economic context of the country, efficiency of the government's policies, as well as an individual economic agent's ability to innovate. And last but definitely not 
the least- issue of trust, present or lacking both vertically and horizontally within the related value chains of the healthcare innovation ecosystem, plays a significant role in defining whenever the economy will or will not perform well innovation management in a well-orchestrated manner. In order to achieve greater value-adding capacity for companies and nations, open innovation ecosystems must be stimulated through encouragement of cooperation incentives and innovation supportive legal and institutional frameworks. Therefore, a further focus on research and development of economic thinking on understanding how the essential ecosystem competence notion, proposed by Katri Valkokari and her colleagues, could be defined in applied economics in order to understand how it is most likely embedded or created within the successful economies for the benefit of improved innovation capacity and the economy's ability to reap faster growth dynamics through faster technological dissemination.

And the final conclusion is that the simple example of putting life science innovations' strategies into the reality of biotechnologies and healthcare sectors in Lithuania shows that even with good incentives of the government, the discrepancies and lack of coordination between the priorities on the macro level, as well as the country specific history of the economy's development, the social context and many other factors lead to a conclusion that just like in medicine one-size does not fit everyone, same is true when analyzing national open-innovation ecosystems. It seems, that the principles of precision medicineto find individual algorithms is needed in order to grasp the patterns which cause significant deviations from logically grounded theoretically desirable principles of efficient open-innovation functioning within the country's economy.

\section{References}

1. The Government of the Republic of Lithuania (2012). Lithuania's Progress Strategy 2030. Internet access: https://lrv.lt/uploads/main/ documents/files/EN_version/Useful_ information/lithuania2030.pdf [accessed January 20, 2019].

2. MOSTA (2018). Executive summary of the questionnaire report on reasons of low cooperation levels between scientific and business institutions in Lithuania "Science and Business cooperation on scientific research and experimental activities" (in Lithuanian only). Internet access: https://mosta.lt/images/ documents/atasakaitos/Mokslo\%20ir\%20 verslo $\% 20$ bendradarbiavimo $\% 20$ MTEP $\% 20$ srityje \%20tyrimo\%20rezultat $\%$ C5\%B3\%20 ataskaita_MOSTA_2018.pdf [accessed January 20, 2019].
3. European Commission (2018). The European Union's Efforts to Simplify Legislation. 2018 Annual Burden survey. Internet access: https:// ec.europa.eu/info/sites/info/files/2018-annualburden-survey_en.pdf [accessed January 28, 2019].

4. European Commission (2016). Better Regulations for Innovation-driven Investment at the EU level. Internet access: https:// publications.europa.eu/en/publication-detail/-/ publication/404b82db-d08b-11e5-a4b501 aa75ed71a1/language-en/format-PDF/ source-79728021 [accessed January 28, 2019].

5. European Commission (2016). Joint Report on Health Care and Long-Term Care Systems \& Fiscal Sustainability. Internet access: https:// ec.europa.eu/info/publications/economyfinance/joint-report-health-care-and-long- 
term-care-systems-fiscal-sustainability-0_en [accessed January 28, 2019].

6. European Commission (2016). Open innovation book: Open innovation. Open Science. Open to the world- a vision for Europe. Internet access: https://ec.europa.eu/digital-single-market/en/ news/open-innovation-open-science-openworld-vision-europe [accessed January 30, 2019].

7. OECD (2015). Highlight of the OECD Science, Technology and Industry scoreboard 2015. Internet access: http://www.oecd.org/sti/ Science-brief-scoreboard.pdf [accessed June 10, 2019].

8. Xu, G., Wu, Y., Minshall, T., Zhou, T. (2017). Exploring Innovation Ecosystems across Science, Technology, and Business: A case of 3D printing in China // Technological Forecasting and Social Change. Vol. 136, pp. 208-221. doi: 10.1016/j.techfore.2017.06.030

9. Jucevicius, G., Grumadaite, K. (2014). Smart Development of Innovation Ecosystem // Procedia - Social and Behavioral Sciences. Vol. 156, pp. 125-129. doi: 10.1016/j. sbspro.2014.11.133.

10. Giest, S. (2019). Trust Dynamics in Innovation Networks: The Chicago Life Science Cluster // Administration \& Society. Vol. 51, Issue 2, pp. 325-324. doi: 10.1177\%2F0095399717701522

11. Valkokari, K, Seppänen, M., Mäntylä, M., JylhäOllila, S. (2017). Orchestrating Innovation Ecosystems: A Qualitative Analysis of Ecosystem Positioning Strategies // Technology Innovation Management Review. Vol. 7, Issue 3, pp. 12-24. doi: 10.22215/timreview/1061

12. Lundvall, B. A., Borrás, S., (2004). Science, Technology and Innovation Policy // The Oxford Handbook of Innovation. Vol. 1. doi: 10.1093/oxfordhb/9780199286805.003.0022.

13. Ramberg, I., Knell, M. (2012). Challenges measuring effects of research and innovation policyinterventionsin ex-postimpactevaluations. A synthesis report. Internet access: https:// www.researchgate.net/publication/260552896_ Challenges_measuring_effects_of_research_ and_innovation_policy_interventions_in_ex-
post_impact_evaluations_A_synthesis_report [accessed August, 27 2019].

14. Varga, A., Sebestyén, T., Szabó, N., Szerb, L. (2018). Estimating the Economic Impacts of Knowledge Network and Entrepreneurship Development in Smart Specialization Policy // Regional studies. Vol. 54, No. 1, pp. 48-59. Doi: 10.1080/00343404.2018.1527026

15. OECD, Directorate for Science, Technology and Innovation. Enhancing Research Performance through Evaluation, Impact Assessment and Priority Setting. Internet access: https://www. oecd.org/sti/inno/Enhancing-Public-ResearchPerformance.pdf [accessed August 27, 2019].

16. European Commission. (2018). Science, Research and Innovation Performance 2018, Chapter I.4. Internet access: https:// ec.europa.eu/info/sites/info/files/srip-reportchap-1-4_2018_en.pdf [accessed November 16, 2019].

17. European Commission, Directorate-General for Economic and Financial Affairs (2015). Efficiency Estimates of Health Care Systems. Internet access: https://ec.europa.eu/economy_ finance/publications/economic_paper/2015/ pdf/ecp549_en.pdf [accessed January 29, 2019].

18. McKinsey \& Company (2019). Precision Medicine: Opening the Aperture. Internet access: https://www.mckinsey.com/industries/ pharmaceuticals-and-medical-products/ourinsights/precision-medicine-opening-theaperture [accessed August 14, 2019].

19. ScienceDirect, online database of scientific and medical research. Internet access: https:// www.sciencedirect.com/topics/social-sciences/ economic-policy [accessed August 15, 2019].

20. Open Innovation community, online platform. Internet access: http://openinnovation.net/ about-2/open-innovation-definition/ [accessed August 15, 2019].

The paper submitted: August 28, 2019

Prepared for publication: December 16, 2019 


\section{Giedrè KVEDARAVIČIENĖ \\ EKONOMIKOS POLITIKA IR ATVIRŲJŲ INOVACIJŲ EKOSISTEMOS BIOMEDICINOS ATVEJU}

\section{S a n t r a u a}

Sparčiai besivystančios technologijos ne tik kuria naujas galimybes ekonomikoje, bet ir formuoja nemenkus iššūkius ekonomikos dalyviams bei vyriausybėms siekiant laiku ir finansiškai pagrịstai kurti ekonominę ir socialinę vertę bei tarptautinị įmonès ir šalies konkurencingumą atitinkamame sektoriuje.

Atvirųjų inovacijų ekosistemos daro itin didelę ịtaką sveikatos priežiūros sektoriui. Senèjant pasaulio visuomenei, didejja su sveikatos priežiūros paslaugomis susijusių technologinių inovacijų svarba ir aktualumas. Nepaisant to, sveikatos priežiūros sektorius vis dar yra viena iš labiausiai fragmentuotų ES bendros rinkos dalių, kai didžioji dalis sprendimų paliekama spręsti nacionaliniu lygmeniu. Žvelgiant ị reikšmingus skirtingų šalių šios srities rezultatų skirtumus, natūraliai kyla klausimai dèl šalių nacionalinių politikų ir jų taikymo mechanizmų objektyvumo ir veiksmingumo, kurie, tikètina, lemia reikšmingus skirtumus šalių gebejjime inovuoti ir generuoti spartesnị šalies ekonominị augimą bei gerejančius socialinès gerovès rezultatus.

Šalies kompetencijos atvirųjų biotechnologijų inovacijų sistemų valdyme siekiant gerinti viešojo sveikatos priežiūros sektoriaus valdymo efektyvumą tampa dar aktualesnès besiformuojant personalizuotai medicinai, kurios kuriamų galimybių iššūkiai atsiranda medicinos produktų, prietaisų ir paslaugų reglamentacijoje, o sveikatos priežiūros paslaugų teikimo tvarka nesugeba atliepti poreikių dèl fundamentalių pastarosios skirtumų, lyginant su lig šiol dominuojančia medicinos pramone. Inovacijų medicinoje dinamika ir stipriai išreikštas rinkos poreikis kokybiškesnems ir efektyvesnèms sveikatos priežiūros paslaugoms skatina greitesnę atvirųjų inovacijų ekosistemų evoliuciją, nei ekonomikos lygmeniu spejama adaptuoti reguliacines aplinkas.

Praktine patirtis rodo, kad atvirosios inovaciju ekosistemos dažnai funkcionuoja nepakankamai efektyviai. Nesèkmingų patirčių istorija, kompetencijų trūkumas tiek valstybiniame, tiek privačiame sluoksniuose, vidiniai ir išoriniai kompleksiškumai, finansinè, socialinè bei reputacinè rizika dažniausiai mažina ekonomikos dalyvių pasitikèjimą, sukuriant papildomą barjerą inovacijų sklaidai .

Teorinès žinos ir empiriniai duomenys sudaro prielaidas tolesnei analizei ir, nepaisant visiems modeliams neišvengiamų ribotumų, indikuoja modeliavimo poreikị, kas padetų analizuoti inovacijų spartą lemiančių sprendimų ir / arba procesų kontekstą, keliant klausimą, kaip igalinti reguliacinę ekonomikų aplinką atliepti skirtingus ekonomikos dalyvių interesus užtikrinant sparčią, bet saugią inovacijų dinamiką, kurioje, vyriausybems reguliacinèmis priemonèmis sumažinus neefektyvumo barjerus, geriau veiktų laisvos rinkos savireguliaciniai procesai. 